\title{
Brains, courage and integrity
}

\section{Gandhi and Sakharov set us an inspiring example for the twenty-first century}

\section{Tom Gehrels}

$\mathrm{M}$ ohandas Karamchand Gandhi (1869-1948) and Andrei Dmitrievich Sakharov (1921-1989) were men of intelligence combined with integrity and the courage of their convictions, even at great personal cost. They were kindred souls, remarkably alike in their use of these attributes for the sake of peaceful progress.

Their original professions were very different. Sakharov's first assignment was to a munitions factory during the Soviet Union's war against Germany, when it was found that he could solve problems, increasingly more difficult, which led to his assignment to the nuclear weapons programme. At first he believed this work was necessary for a balance of power, but gradually his conscience drove him to consider the related issues of human rights and survival for the whole world. Gandhi began with studying for a law degree in England, but later, as a lawyer in South Africa, he found that his views on independence and human rights led him to develop a successful new career.

Gandhi and Sakharov were equally bright and courageous people, setting themselves goals to achieve, even at the cost of repeated hunger strikes. Gandhi tried desperately but unsuccessfully to prevent the partition of colonial India into the separate states of India and Pakistan. However, he saved many lives during the frictions between Hindus and Muslims. Sakharov was able to exert a powerful influence in the Soviet Union and on Premier Khrushchev, because he had originally worked within their system. A dissident of lesser status would have simply 'disappeared', but instead he was exiled to Gorky with his wife, and the news of his hunger strikes kept leaking out. The nearly terminal sufferings of both Gandhi and Sakharov made the deepest impression on their people and their leaders. Finally, Premier Gorbachev allowed Sakharov to return from Gorky to Moscow, at a critical time when the balance was swung towards democracy rather than towards disastrous international confrontation.

The intellects of both men and their acts of courage were guided by integrity. In Gandhi's opinion,

\section{As a splendid palace}

deserted by its inmates

looks like a ruin,

so does

a man without character,

all his material belongings

notwithstanding.

The possible consequences of their actions never prevented either man from doing what he perceived to be right. At the very beginning of his involvement with dissident issues, in 1966, Sakharov was asked to sign a statement against Stalin's rehabilitation, a dangerous subject at the time, but he writes simply: "I read his draft letter, found nothing objectionable in it, and added my signature."

However, Gandhi and Sakharov were not helpless martyrs: they both knew how to make the best political use of the sacrifices they made. Another character trait they shared was an openness of manner, combined with a certain detachment, an ability to compromise on the spot. Gandhi was always willing to negotiate:

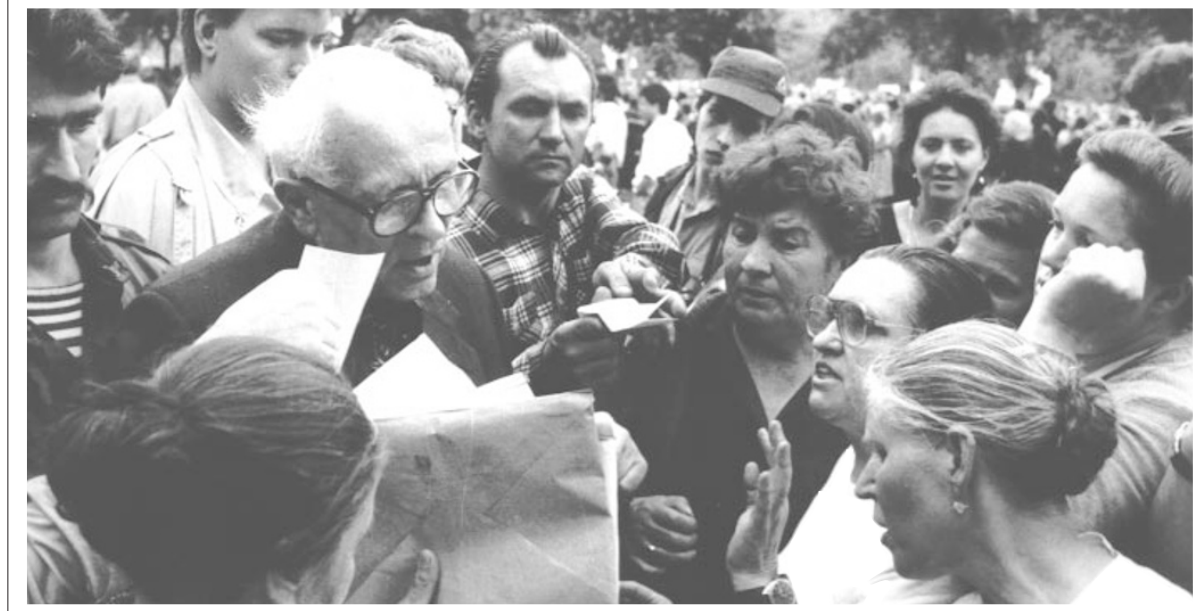

Sakharov surrounded by the electorate at the Congress of the USSR People's deputies in May 1989.

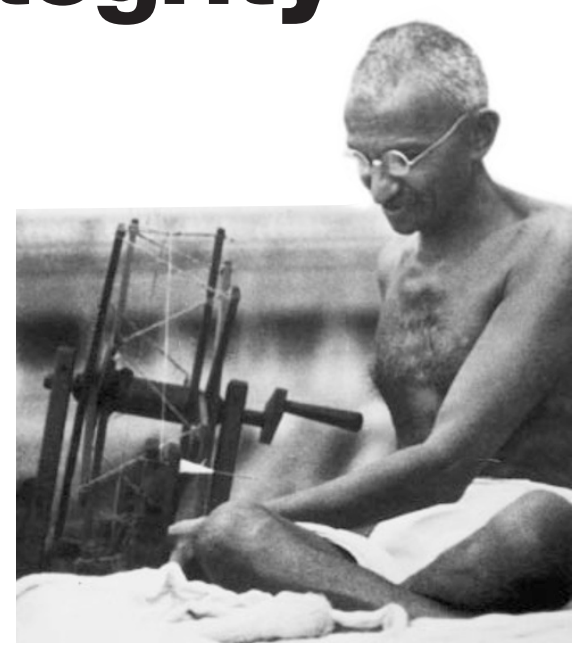

Gandhi at a spinning wheel during a demonstration in India, June 1925.

But all my life through,

the very insistence on truth

has taught me to appreciate

the beauty of compromise.

And they were always willing to try again. Gandhi said:

Satisfaction lies in the effort,

not in the attainment.

Full effort

is full victory.

and

Life is an aspiration.

Its mission is

to strive after perfection

which is self-realisation.

Sakharov lived by an epigraph in Goethe's Faust:

He alone is worthy of life and freedom who each day does battle for them anew.

We can learn a great deal about a person from the way he judges others. Sakharov provides an insight into his moral convictions when he describes one of his favourite professors as having "absolute intellectual integrity and courage, willingness to reexamine his ideas for the sake of truth, and readiness to take action."

The legacy of the two pioneers may serve to guide humanity in the twenty-first century. Gandhi's warnings and hunger strikes protesting against ethnic cleansing are still important teachings today. Although Sakharov was weakened by his exile and did not live long enough to help guide the new Russia, he left us practical advice in his Memoirs and other writings. Thus, the lawyer and the engineer who fought for such similar ideals have left a literature to prepare us for future crises. They may also be role models for us as individuals, setting examples of personal integrity and common sense, and the courage to rise above adversity when it comes.

Tom Gehrels is in the Department of Planetary Sciences, University of Arizona, Tucson, Arizona, USA. 